\title{
rdw Rats, a New Hereditary Dwarf Model in the Rat
}

\author{
Masao KO'TO, Tsuyoshi SATO, Michio OKAMO'TO, \\ and Jiro ADACHI
}

\begin{abstract}
Drug development laboratories, CHUGAI pharmaceutical Co., Ltd. Takada 3-41-8, Toshima-ku, Tokyo 171, Japan.
\end{abstract}

(Received 1 May 1987/Accepted 2 September 1987)

\begin{abstract}
A new hereditary dwarf mutation was found in Csk: Wistar-Imamichi rat breeding colony. The mutant rats and control normal rats were studied with clinical, genetical and histological examination. The result showed that the present mutation was inherited in autosomal recessive trait (gene symbol; $r d w$ ) and was provoked with the hypoplasia of pars distalis (anterior pituitary), in particular the secretory cells of GH, PRL and TSH. The characteristics of the present mutant $(r d w)$ was very similar to $d w$ mouse, and was usefull for endocrinological research as an animal model of human pituitary dwarfism.
\end{abstract}

新しい遺伝性侏儒症モデルラット $(r d w)$

古藤正男·佐藤毅问・岡本道生・安達二朗

中外製桨俰開発研究所

先天性侏儒症のモデル動物として, マウスでは Snell's dwarf(dw)[17], Ames dwarf(df)[16], Pigmy(pg) [9], Little(lit)[5]等があり, 内分泌研究の好材料とし て活用されている。とくに Snell's dwarf(dw) は 1929 年に発見されて以来, その病態はもちろんのとと病態之 関連する内分泌領域についても多くの研究がなされてい る。また, Snell's dwarf(dw) や Ames dwarf(df) は 胸腺退縮や免疫不全がみられることから胸腺免度系に関 する研究材料としてあ注目されている [19]。

一方, ラットでは1935年に $d w-1[11], 1939$ 年に $d w-2$ [22]が発見されているがてれらの系統に関してのその後 の報告はない。最近, 大熊らにより Sprague-Dawley 系 から GH 単独欠損侏儒症のラット $(d r)$ が見いだされて いる $[13-15]$ 。

当研究所で 1960 年よる 維持している Csk：Wistar-
Imamichi 系ラットクローズドコロニーの一腹から同腹 子 7 匹の中に極端に体型の小さい個体 4 匹を発見した。 両親および正常同腹子同士の交配により同様のラットが 出現し遗伝性の侏儒症と思われた。そこでその発症を遺 伝的に固定して, 新しい侏儒症モデルラットを作出し, $r d w$ 系亡命名した。

本報告はこれまでに得られた成績をまとめ，本ラット における発育成長と遺伝様式抢よび組織所見について報 告するあのである。

\section{材料亡方法}

動物： $r d w$ 系の発症個体および正常同腹個体を用いた。 また交配実験には F344/DuCrjCsk 系を用いた。 飼育条件：動物はカンナ屑を敷いたポリカーボネイト製 
ケージ $(265 \times 425 \times 160 \mathrm{~mm})$ に 5 匹を収容して, 市 販固形飼料（日本クレア: CE-2）および水道水と井戸水 の混合水を不断に与え, 温度 $24 \pm 2^{\circ} \mathrm{C}$, 湿度 $50 \sim 60 \%$, 5 時点灯19時消灯に設定された動物窒で飼育した。正常 個体は生後 3 週秢, 侏儒症個体は生後 5 週㱓にて離乳し た。

体重测定及び観察：入墨またはピクリン酸で 個 体識 別 し，21日齢までは毎日，その後15週龄までは週 1 回体重 を測定した。また, 次週までの増加体重を前週の体重で 除して 100 を乗じて週当りの体重増加率（\%）を算出し た。また, 上下両切歯の萌出, 左右両側の開眼, 腔開口 について毎日観察した。これらの項目が確認された日齢 についての有意性の検定には $\mathrm{t}$ 検定を用いた。

化骨成熟度：5〜11 の各週龄で左後肢をX線撮影して比 較した。X 線撮影には軟 X 線撮影装置( SOFRON : SRO M50C) および軟 $\mathrm{X}$ 線撮影用フィルム（Fuji FG）を用 い, 電圧 $40 \mathrm{kVp}$, 電流 $4 \mathrm{~mA}$, 距離 $40 \mathrm{~cm}$, 露出 1 分の均 一条件下で撮影した。

臓器重量: 10週路に拎いて放血と殺後解剖し, 主要臓器 を科量した。比体重値を算定し, 正常例の比体重值を 1.00 としたときの侏懦症例のそれを比体重係数として算 出した。

組織学的観察： 5 週龄, 15週龄, 25 週跘の発症個体およ び正常同腹個体の雌雄各 1 例から内分泌系臓器, 主要臓 器, 後肢膝関節を採取し, $10 \%$ ホルマリンまたはソルチ ア固定液で固定した。後肢膝関節については脱灰を行っ
た。常法に従ってパラフィン包埋した後, $5 \mu \mathrm{m}$ の薄切片 を作成し, H-E 染色の他必要に応じてアザン染色, PAS 染色等の特殊染色を行った。また，15週齢については下 垂体の内分泌細胞同定の為，ヒト用酵素抗体法染色キッ ト（PAPKIT K514，517）を用いて PAP 法[19]による 酵素組織化学的染色を行うとともに, 下垂体を $2.5 \%$ グ ルタールアルデヒド, オスミウム酸による 2 重固定後, エポン樹脂に包埋したのち超薄切片を作製し, 酢酸ウラ 二ウム,クエン酸鉛の 2 重電子染色を行い, 電子顕微鏡 （日本電子：JEM : 100S）による観察を行った。

生殖能力: 雌の侏儒症個体 5 匹について胵開口後, 腔ス メアを採取して発情前期像を示した日に正常な雄と同居 させた。雄の侏儒症個体 6 匹については腔インピーダン ス法 [10］により交配適期と判定された正常な雌と同居 させた。また侏儒症同士においても同様に同居させ，侏 儒症個体の生殖能を検討した。乙れらの検査は15週路以 後において実施した。

交配実験：雄の侏儒症と F344/DuCrjCsk 系およびその F1 を用いて交配実験を行った。それぞれの交配による 発症個体の出現率についてはカイ二乗検定により検定し た。

成

3 腹から得られた侏儒症例 10 匹と正常例 76 匹の生後 21 日粭までの体重を Fig. 1 亿示した。侏儒症個体を各

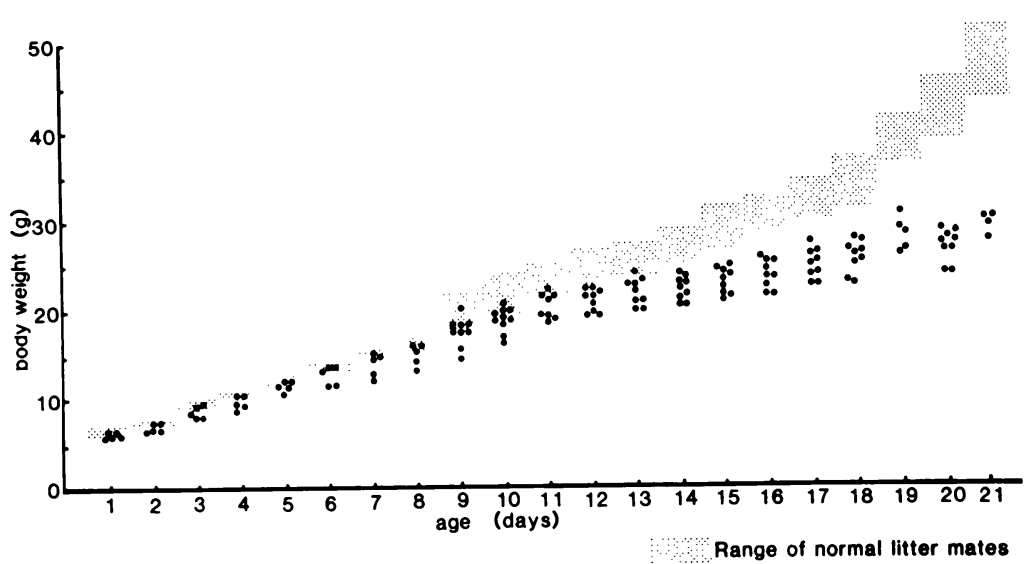

Body weight of $10 \mathrm{dwarf}$ and 16 normal rats ( 3 litters) were measured. Body weights of the dwarfs $(\bullet)$ tend to be light at birth and fall below the range of body weight of normal rats (\%) after one week of age.

Fig. 1. Body weight of dwarf rats during the first 21 days of life. 
プロットで示し，侏儒症が発症した腹の正常腹子の体重 域を階段状に示した。なお21日柃までは体重に性差がみ られなかったととから雌雄別にはしなかった。侏儒症個 体は 1 日齿では同腹子の中で低い体重傾向を示し, 正常 同腹子体重域の下限付近にあった。2 日齡より正常同腹 子体重域を下回る個体が見られ始め，14日齢以後では全 ての侏儒症個体が正常同腹子体重域の下限以下になり, その後正常個体との体重差は広がった（Fig. 1)。1 15 週路までの侏儒症と正常例の平均体重推移を Fig. 2 亿示 した。侏儒症の正常例に対する体重の割合は, 3 週齢で 雄 59\%, 雌 57\%，4 週龄で雄 30\%, 雌 33\%，6 週齢で 雄 23\%, 雌 26\%, 10週秢で雄 35\%, 雌 38\%，15週齢で 雄 $41 \%$, 雌 $46 \%$ であった。雄では 2 週齢から, 雌では 3 週路からそれぞれ正常例との間に有意な差が認められ た。また体重に性差が認められるのは正常例では 4 週粭 からであったが, 侏儒症では 8 週齢からであった(Fig.2)。

1 週齢から11週路までの侏懦症と正常の週当りの体重 增加率をFig. 3 に示した。1〜2週秢に拉ける侏儒症の 体重増加率は正常例とほとんど差がなかったが，その後 正常例では $3 \sim 4$ 週踰に㧍ける雄 115\%, 雌 $82 \%$ を最高 に 2 週跘加 5 週龄にかけて增加率が大きいのに対し， 侏儒症ではほとんど增加しなかった。しかし，正常例の 体重增加率が下降している $6 \sim 7$ 週秢あるいは $7 \sim 8$ 週 秢において比較的大きい増加率を示しており, その増加 率は雄の $6 \sim 7$ 週龄で 56\%，雌の $7 \sim 8$ 週龄で $30 \%$ で あった (Fig. 3)。

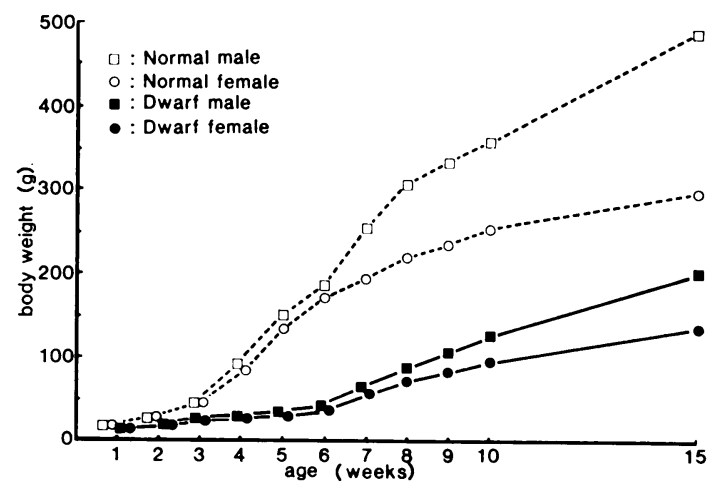

Average body weights are shown at each age in weeks. Dwarfs are significantly lighter than normal rats after 2 weeks of age in males and after 3 weeks in femals. A significant sexual difference in body weight appears after 4 weeks of age in normal rats, and after 8 weeks in dwarfs.

Fig. 2. Growth curves in normal and dwarf rats.

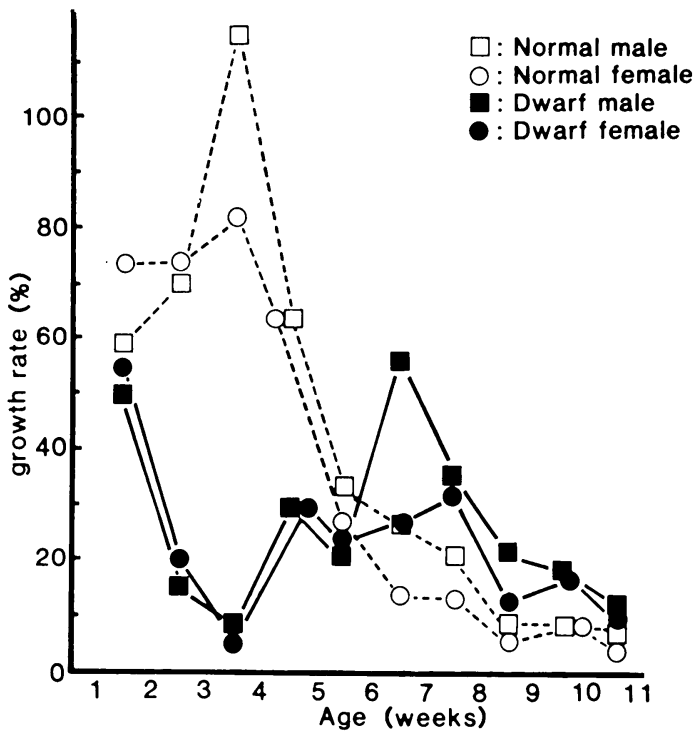

The growth rate is high at 3 to 5 weeks of age in nomal rats. But in dwarf rats, it is moderate at 6 to 7 weeks of age compared with the low rate at 3 to 5 weeks of age.

Weekly growth rate (WGR): (Body weightbody weight 7 days before)/Body weight 7 days before. The marks show the average of individual WGR of 10 rats in each group.

Fig. 3. Weekly growth rate.

切歯の萌出, 開眼, 窑の開口が認められた日齢を Table 1 亿示した。正常例と侏懦症のそれぞれの項目に ついて, 認められた日齢の範囲と平均を示した。切歯の 萠出が認められたのは正常例が 11 14 日齢, 平均 11.7 日齢であるのに対し，侏儒症は 13〜18 日齢，平均 15.2 日齡であり，3.5 日の遅延が認められた。同様に開眼に む 3.5 日の遅延がみられ, 腔の開口は侏儒症で $33 \sim 41$ 日 秢之範囲が大きく平均日齢で 6.2 日の遅延が認められた (Table 1)。

15週齢の雄の侏儒症個体（右）と正常同腹雄（左）を Fig. 4 亿示した。侏儒症個体は一見して体形が小さく，

Table 1. Incisor eruption, Eyelid opening and Vagina opening.

\begin{tabular}{|c|c|c|c|c|c|c|}
\hline \multirow{2}{*}{ Item } & \multicolumn{3}{|c|}{ Normal } & \multicolumn{3}{|c|}{ Dwarf } \\
\hline & $\mathrm{n} \mathrm{r}$ & range $^{\mathscr{A}}$ & mean $^{\mathrm{a}}$ & $\mathrm{n}$ & range & mean \\
\hline Incisor eruption & 6 & $11-14$ & 11.7 & 6 & $13-18$ & 15.2 \\
\hline Eyelid opening & 19 & $14-17$ & 16. 6 & 14 & $19-21$ & 20.1 \\
\hline Vagina opening & 8 & $29-34$ & 30.8 & 5 & $33-41$ & 37.0 \\
\hline
\end{tabular}




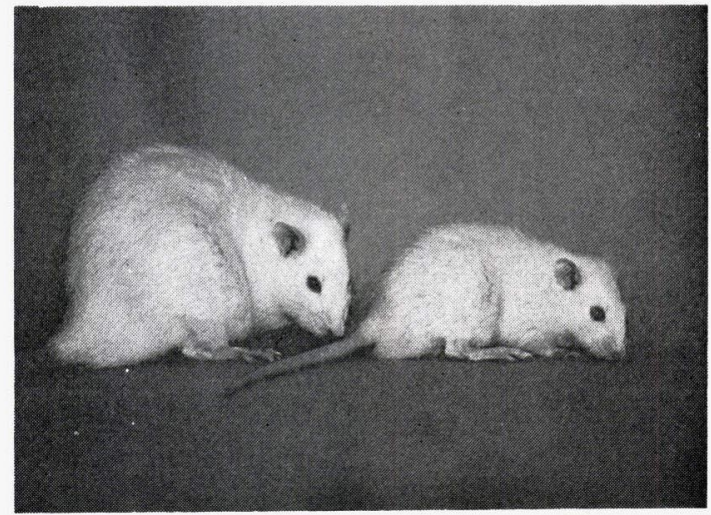

Fig. 4. Male dwarf (right) and normal litter mate (left) at 15 weeks of age. The dwarf shows small body size and has soft hair and a short thin tail.

被毛は剛毛とはならず, 細く柔らかであった。また, 尾 は細く短かった (Fig.4)。

5 週秢と 10 齿週におりる正常例と侏儒症の左後肢のX 線像を Fig. 5 に示した。侏儒症では化骨成熟が著しく遅 延しており, 5 週㱓では足根骨, 膝関節は未発達であっ た。10週龄の侏儒症の骨端核化骨成熟度合は，正常例の 5 週龄と同程度の状態にまではなっていたが，骨体部の
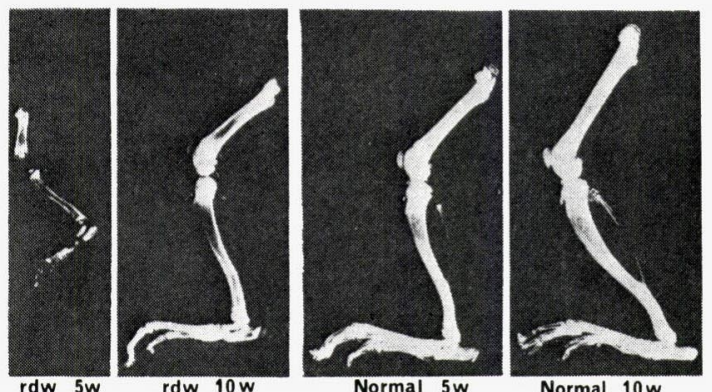

The ossification of the osteoepiphysis in dwarfs is immature and decreased absorption of X-ray appears in the diaphysis (long born). The maturation of dwarf bone at 10 weeks of age is nearly equal to that of the normal rat at 5 weeks of age.

Fig. 5. X-ray photographs of the left hind-limb of dwarf and normal rats at 5 and 10 weeks of age.

\section{X線吸収は低かった (Fig. 5)。}

10週龄における主要臓器の重量を Table 2 に示した。 侏儒症の主要臓器の重量はほとんどが正常例の 40 ～60\% 程度であり, 比体重係数は 1.00 前後であった。しかし, 大脳之精巣の重量は正常例之同程度であり, 比体重係数 あそれぞれ 2.20，2.41 と大きかった(Table 2)。

Table 2. Body weight and organ weight of Dwarf/Normal rats at 10 weeks of age.

\begin{tabular}{|c|c|c|c|c|c|c|c|}
\hline \multirow[b]{3}{*}{ Body Weight(g) } & \multicolumn{3}{|c|}{ Dwarf } & \multicolumn{3}{|c|}{ Normal } & \multirow{3}{*}{$\begin{array}{l}\text { coeficient } \\
\text { of ROWe }\end{array}$} \\
\hline & \multicolumn{2}{|c|}{ female(13)a } & male(14) & \multicolumn{2}{|c|}{ female(12) } & male $(10)$ & \\
\hline & $101 \pm$ & $10^{\mathrm{b})}$ & $126 \pm 10$ & $256 \pm$ & $=19$ & $364 \pm 14$ & \\
\hline \multicolumn{8}{|l|}{ Organ Weight(mg) } \\
\hline Brain & $1472 \pm$ & 64 & $1526 \pm 96$ & $1804 \pm$ & 66 & $1921 \pm 55$ & 2.20 \\
\hline Pituitary & $5.6 \pm$ & 1.5 & $6.1 \pm$ & $12.9 \pm$ & 1.6 & $10.4 \pm \quad 0.9$ & 1.48 \\
\hline Thyroid & $17.1 \pm$ & 3.5 & 18. $3 \pm$ & $27.5 \pm$ & 4.1 & $41.6 \pm$ & 1.36 \\
\hline Thymus & $168 \pm$ & 24 & $224 \pm 31$ & $357 \pm$ & $=50$ & $547 \pm 115$ & 1.26 \\
\hline Heart & $313 \pm$ & 22 & $409 \pm 54$ & 826 & 52 & $1190 \pm 67$ & 0.99 \\
\hline Liver & $5141 \pm$ & 776 & \pm 1097 & 15444 & 上 1312 & $22618 \pm 1514$ & 0.82 \\
\hline Spleen & 223 & 30 & $291 \pm 40$ & $629 \pm$ & $\pm \quad 52$ & $893 \pm 312$ & 0.92 \\
\hline Kidneys & $953 \pm$ & 113 & $1269 \pm 180$ & $2353 \pm$ & \pm 253 & $3776 \pm 257$ & 1.00 \\
\hline Adrenals & $33.5 \pm$ & 4. 4 & $30.2 \pm \quad 3.6$ & 83. $0 \pm$ & $=18.6$ & $75.3 \pm 12.8$ & 1.09 \\
\hline Ovaries & $57 \pm$ & 18 & & $122 \pm$ & $\pm \quad 17$ & & 1. 17 \\
\hline Testes & & & \pm 982 & & & $3109 \pm 144$ & 2.41 \\
\hline Epididymides & & & $285 \pm 43$ & & & $772 \pm 67$ & 0.67 \\
\hline Vent. Prostate & & & $200 \pm 89$ & & & $517 \pm 59$ & 0.77 \\
\hline M. Gastrocnemius & 496 & 90 & \pm 101 & 1411 & \pm 161 & $1718 \pm 545$ & 0.89 \\
\hline
\end{tabular}

a: Number of rats.

$\mathrm{b}:$ mean $\pm \mathrm{S}$. D.

c: dwarf ROW/normal ROW (ROW : relative organ weight). 

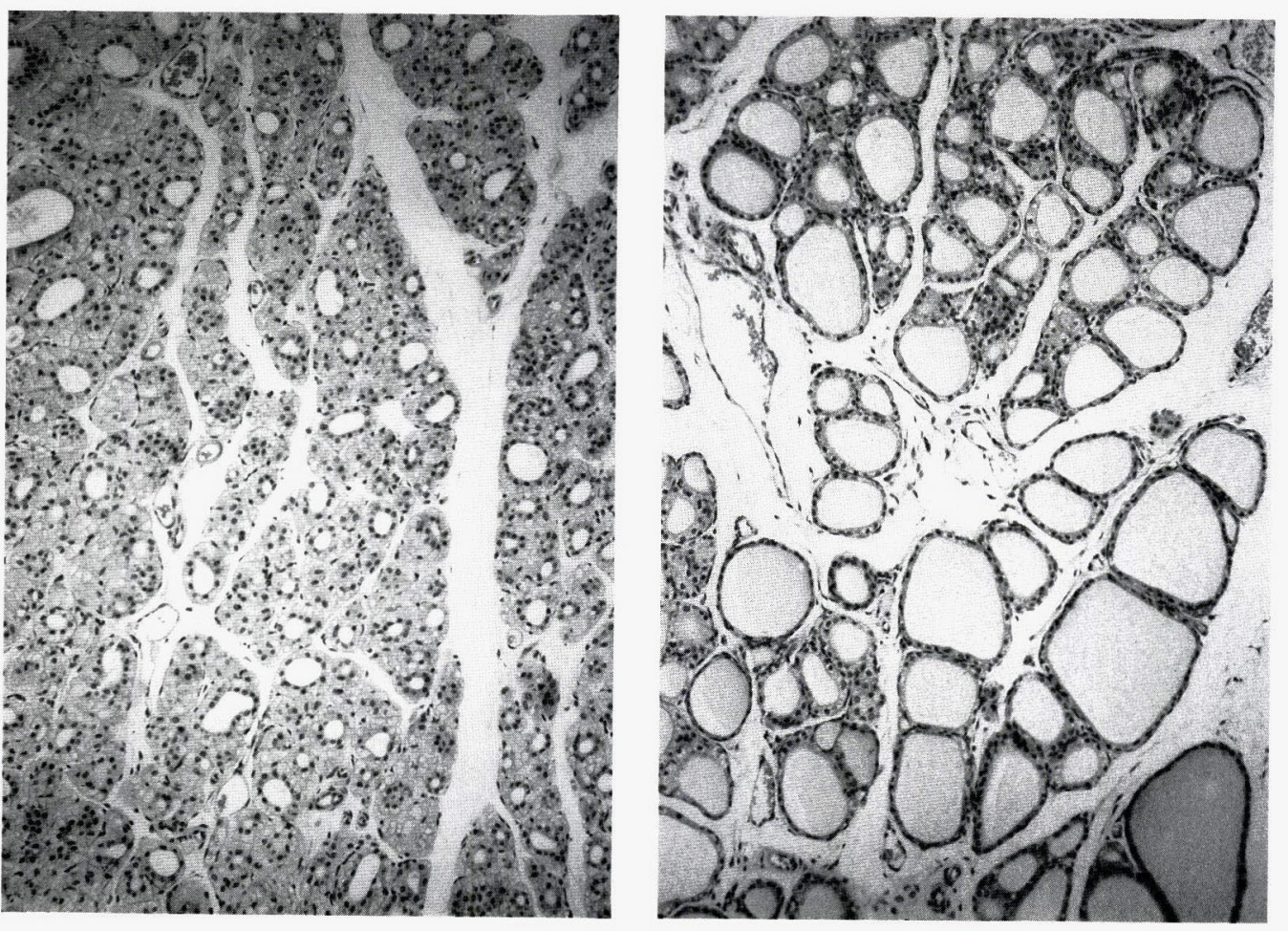

In norml tissue, many large follicles containing colloid substance appear (left). In dwarf, there are numerous small follicles, but no colloid substance in these follicles (right).

Fig. 6. Thyroid glands at 5 weeks of age (HE stain).

組織学的検査の結果, 5 週齢において侏儒症例の骨成 長部, 下垂体前葉，甲状腺，精巣で正常例とは明らかな 差異が認められた。副腎をはじめ卵巣, 副生殖腺, 肝, 腎ほか主要藏器は正常例と差がなかったため, 15および 25週歯㱓における観察は前述の差異の認められた簓所に ついてのみ行った。

長骨骨端の骨成長部は, 5 週龄では正常例に比べ軟骨 増生帯の幅が狭く, 骨化核の化骨は遅延し, 骨棱は未発 達で骨芽細胞も少なかった。15週龄でも同様の所見であ ったが，25週齢になると正常例では軟骨増生帯の幅が狭 くなり骨成長の終了を示していたのに対し，侏需症例で は幅が広くなっており未だ骨成長途上であるととを示し ていた。

下垂体前葉は，5週齢では正常例が多数の酸好性細胞 および塩基好性細胞から構成されているのに対し, 侏儒 症例のそれはほとんど色素嫌性細胞からなり, 一部散在 性に少数の酸好性細胞, 塩基好性細胞を認めるにとどま った。侏懦症では15週粭になると 5 週秢に比べ塩基好性 細胞は明らかに増加していたが, 酸好性細胞の増加はほ とんどなかった。25週齢であ15週齢時と同じであった。
甲状腺は, 5 週龄では正常例がろ胞内にエオジン好性 コロイドを豊富に認め, 既にサイロキシン (T 4) 分泌を 行っている像を示していたのに対し, 侏懦症ではろ胞構 造は見られるあのの, 全体に小型のものからなり内腔に 分泌物はほとんど認められなかった (Fig. 6)。

精巣は, 正常例では 5 週齢で既に精子形成が成されて いた。これに対し, 侏儒症では精細管の直径が小さく, 精細胞は第 2 精母細胞の段階にとよ゙まり, 精子形成は認 められなかった（Fig. 7)。15週齢になると，精子形成が かなりの精細管で認められるようになった。しかし, 内 腔がやや拡張し精子形成が認められない精細管も見られ た。25週齢でも同様の所見であった。

15週齢での下垂体前葉の酵素組織化学的検討の結果, 成長ホルモン $(\mathrm{GH})$, プロラクチン (PRL), 甲状腺刺激 ホルモン (TSH) の陽性細胞は, 侏儒症例では正常例に 比べ明らかに少なかった（Fig. 8)。下垂体前葉細胞 100 個当りの各種ホルモン陽性細胞数を Table 3 に示した。 GH, PRL, TSH の陽性細胞数は, 侏儒症例では正常例 に比べ明らかに少なく, GH, PRL は雄の方がより少な かった。副腎皮質刺激ホルモン (ACTH) 陽性細胞数は, 

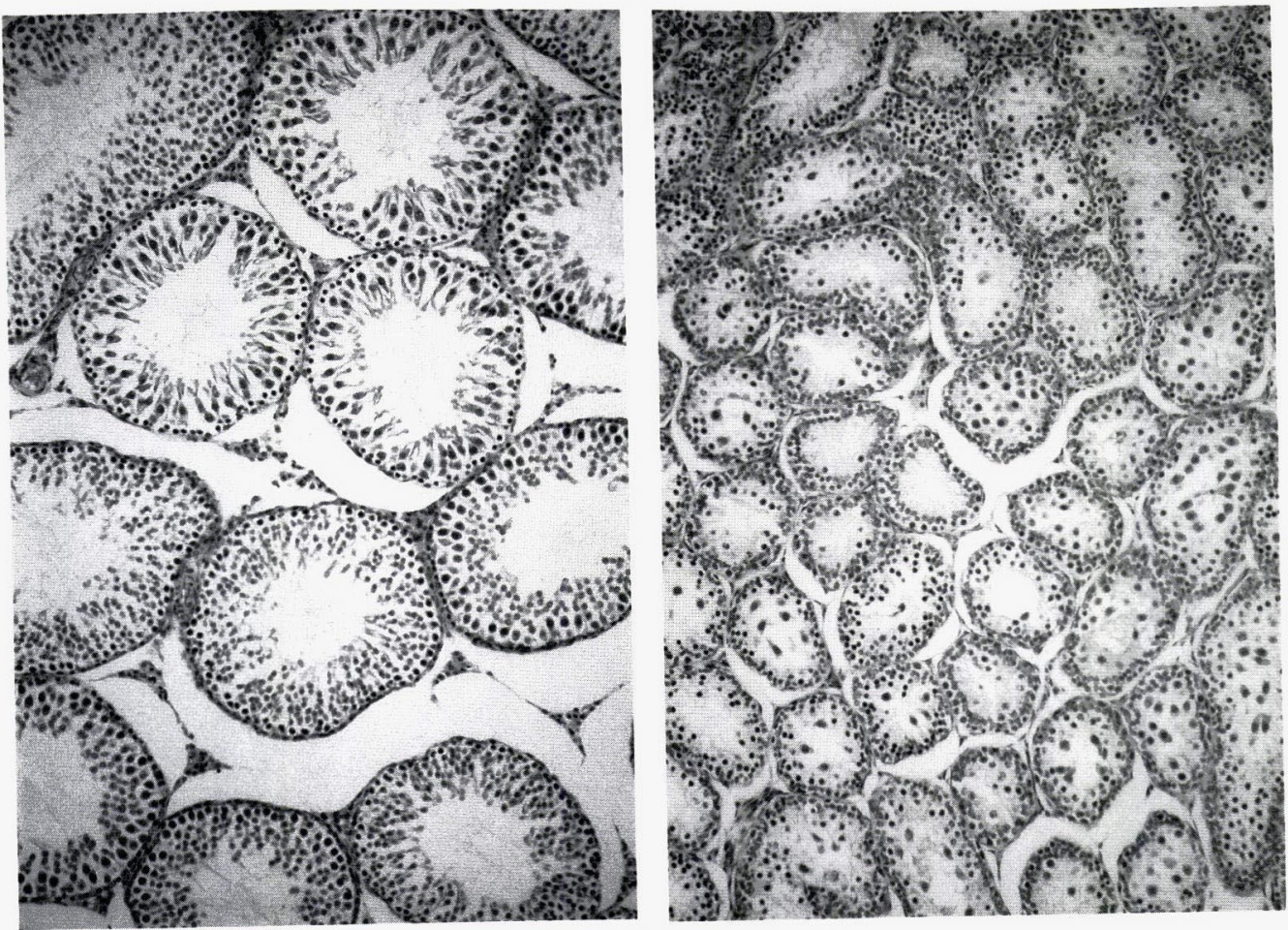

Pictures show normal tissue on the left and dwarf on the right. In dwarf, the diameters of the seminiferous tubules are decresed and the spermatogenesis is halted at the secondary spermatocyte stage. Spermatids and spermatozoa are not found at 5 weeks of age, but appear after 15 weeks of age.

Fig. 7. Seminiferous tubules of testes at 5 weeks of age (HE stain).

Table 3. Approximate distribution of anterior pituitary cell type.

\begin{tabular}{llcc}
\hline Cell type & Sex & Normal(\%) & Dwarf(\%) \\
\hline GH & Male & 65.5 & 6.7 \\
& Female & 45.6 & 20.3 \\
PRL & Male & 20.0 & 1.0 \\
& Female & 36.1 & 7.1 \\
TSH & Male & 7.0 & 3.2 \\
& Female & 3.9 & 1.2 \\
ACTH & Male & 10.0 & 8.9 \\
& Female & 9.9 & 7.0 \\
LH. FSH & Male & 8.0 & 11.0 \\
& Female & 6.5 & 11.4 \\
\hline
\end{tabular}

The distribution rates are based on abservations of an area of the middle part of the anterior pituitary and was caluculated as follows. 〈Distribution rate $=$ Number of immunohistochemically positive cells/Total parenchymal cells>
正常例とあまり差はなく, 性腺刺激ホルモン (LH-FSH) 陽性細胞数は侏懦症例の方が多い傾向にあった（Table 3)。

15週齢の下垂体前葉の電子顕微鏡像を Fig. 9 亿示した。 侏儒症例では正常例に比へ, 分泌顆粒含有細胞が少なか った。また含有している顆粒の大きさについても差異を 認めた。正常例の $G H$ や PRL 分泌細胞に見られるよう な直径 300〜350nm 以上の顆粒を含む細胞は極めて少な く，多くは直径 $200 \mathrm{~nm}$ 位の顆粒を含有していた（Fig. 9)。

侏儒症雌の臸スメア像の検査の結果, 性周期の律動が 観察された。発情前期像を示した日に正常な雄と同居さ せたととろ, 全例 $(5 / 5)$ において翌朝, 落下した臸栓と 胵内に精子を認め，交尾が成立したととを示していたが， 妊娠は成立せず不妊であった。一方, 雄については全例 （6/6）が生殖能を有しており，正常雌を妊娠させた。ま た侏儒症同士の交配では交尾したが妊娠は成立しなかっ た。 

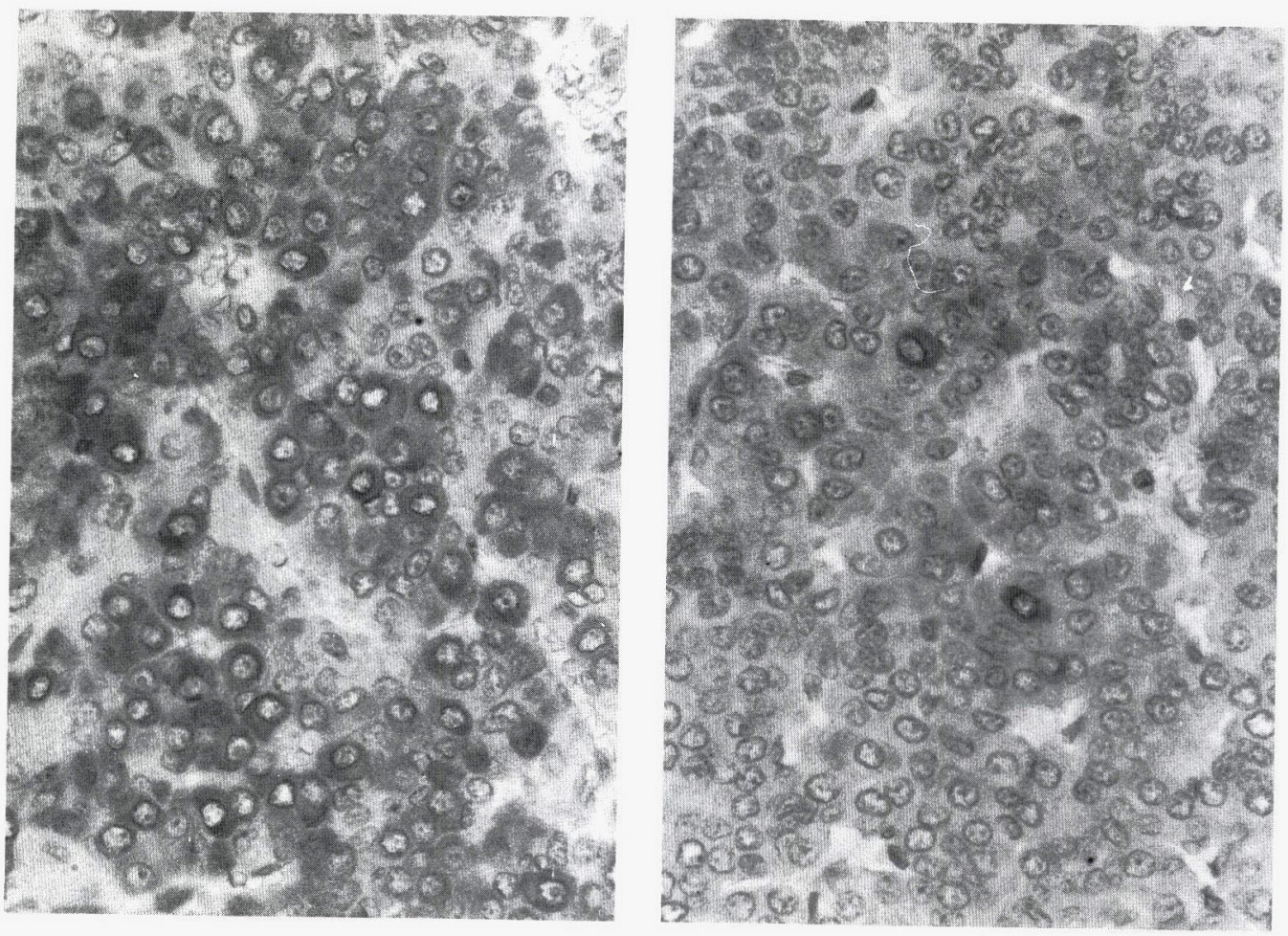

The pictures show normal tissue on left and dwarf on right. Note the marked decrease in the number of positive cells in dwarf.

Fig. 8. GH positive cells in anterior pituitary stained by the immunohistochemical method (PAP).

Table 4. Segregation of dwarfism in crossbreedings.

\begin{tabular}{|c|c|c|c|c|c|}
\hline \multirow{2}{*}{\multicolumn{2}{|c|}{ Female $\times$ Male }} & \multirow{3}{*}{$\begin{array}{c}\text { Number } \\
\text { of } \\
\text { litters }\end{array}$} & \multicolumn{3}{|c|}{ Number of pups } \\
\hline & & & \multirow{2}{*}{$\begin{array}{c}\text { Total } \\
10\end{array}$} & \multirow{2}{*}{$\frac{\operatorname{Normal}(\%)}{10(100.0)}$} & \multirow{2}{*}{$\frac{\operatorname{Dwarf}(\%)}{0(0)}$} \\
\hline Normal F344 & Dwarf & & & & \\
\hline $\mathrm{F} 1$ & F1 & 5 & 71 & $54(76.1)$ & $17(23.9)$ \\
\hline F1 & Dwarf & 2 & 25 & $12(48.0)$ & $13(52.0)$ \\
\hline $\mathrm{F} 1$ & Normal F344 & 2 & 19 & $19(100.0)$ & $0(0)$ \\
\hline
\end{tabular}

F1 = Normal F344 female $\times$ Dwarf male.

交配実験成績をTable 4 亿示した。侏儒症の発症率は 正常 F 344 系と侏儒症個体の交配で 0\% (0/10), F 1 同 士の交配で $23.9 \%(17 / 71)$, 侏儒症への戻し交配で 52.0 $\%(13 / 25)$, F 344 系への戻し交配で 0\% (0/19) であり, 発症率に性差はなかった。

\section{考察}

侏儒症個体は生下時より低体重傾向にあり, その後の 体重増加, 特に $2 \sim 6$ 週秢における体重増加は正常に比 べ著しく劣っていた。体重増加率からみた急成長時期の
遅延が明らかとなり，切蒾萌出，開眼，腔開口などの発 育成長の指標についてむ遅延していた。また骨の成長に ついても遅延が認められた。後肢骨のX線写真像におい て侏儒症では著しい骨端核化骨成熟遅延が認められ，骨 成長部の組織像からも同様の所見が得られたととから， 造骨期間が延長していることが判明した。すなわち，乙 の侏儒症は単に体形が小さいというだけでなく, 発育の 遅延, 延長そして不完全な形での成熟といった正常とは 異なる発育成長パターンを示していると考えられた。

下垂体前葉のアザン染色光顕像で酸好性細胞の減少が 認められ, 同部位の酵素組織化学的な検討に拈いて GH, 

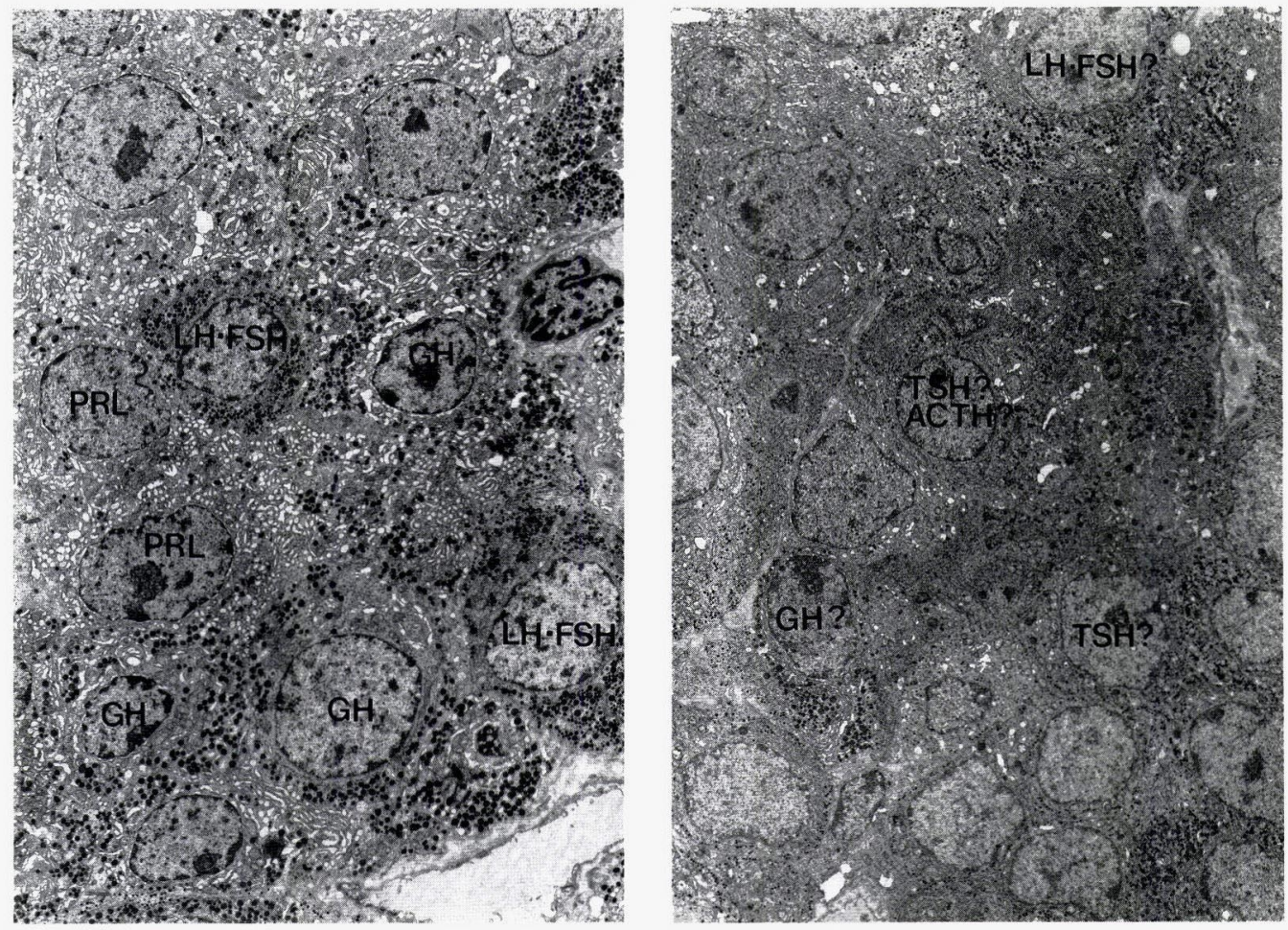

There are very few cells containing granules in the dwarf. The miniaturization of granules (under $200 \mathrm{~nm}$ diameter) makes it difficnlt to classify cell types.

Fig. 9. Anterior pituitary of normal (left) and dwarf (right) at 15 weeks of age $(\times 2000)$.

PRL，TSH の陽性細胞の著しい減少が認められた。ま た電顕像では分泌顆粒含有細胞が減少しており，正常例 の $\mathrm{GH}, \mathrm{PRL}$ 産生細胞にみられるような直径 300 350 $\mathrm{nm}$ 以上の大型顆粒を含む細胞は少なかった。

侏儒症モデルにおける下垂体前葉の電顕的観察は $d r$ ラットや lit, $d w$ 等のマウスでの報告がある。 $d r$ ラッ トでは, $\mathrm{GH}$ 分泌細胞に特徵的な電子密度の高い直 径 250〜350nm の顆粒を持つ細胞は全く認められず，TSH 分泌細胞や Gonadotroph は正常ラットと同様に認めら れたとしている $[15]$ 。

lit マウスでは少数ながら $\mathrm{GH}$ 分必細胞は認められ, これは正常例に比べ顆粒の直径および数が減少していた と報告されている $[2] 。 一$ 方 $d w$ マウスでは不規則な 形の細胞や星形の細胞を認めるものの, 典型的な $\mathrm{GH}$ 分 泌細胞や PRL 分泌細胞は認められず, 両者の特徴を有 した Somatotroph·mammotroph-like cell が見られた

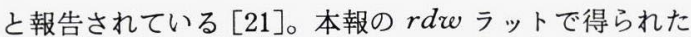
所見は，この $d w$ マウスの報告に比較的近いものである と考えられた。 $r d w$ ラットでは $\mathrm{GH}$ 分泌細胞と思われ るあのがごく少数認められたのみで PRL 分泌細胞と思
われる多形大型顆粒を持つ細胞は認められず, 顆粒直径 からみるとGonadotroph と思われる細胞が多数を占め ており, 酵素組織化学的な検討結果との間に違いがみら れた。これは, 酵素組織化学的に GH 陽性, PRL 陽性 あるいは TSH 陽性であった細胞は, これらのホルモン を産生していることは間違いないが, 細胞形態としては 成熟分化しきっておらず，形態からでは判別できないた めと考えられた [23-28]。

近年, ラットで $\mathrm{GH}$ 分泌細胞の一部は PRL を同時に 分泌していることが報告されており [6]，ヒトの下垂体 腺腫では $\mathrm{GH}$ と PRL を同時に産生する mammo-somatotroph cell の存在が認められている $[7] 。 r d w ラ ッ ト$ の下垂体前葉に抢いても，形態的に分化しきっておらず 判別できない内分泌細胞がわずかながらもホルモンを産 生している可能性がある。これらのことから, 先に述べ た一連の発育成長遅延および不全は, 下垂体前葉の $\mathrm{GH}$, TSH 分泌細胞の減少，分化不全に起因したものと考え られる。

甲状腺でろ胞形成不全が認められた。この変化は下垂 体前葉の TSH 分泌細胞の減少に起因する二次的変化で 
Table 5. Characteristics of animal models of dwarfism.

\begin{tabular}{|c|c|c|c|c|c|c|c|}
\hline \multirow{2}{*}{ Mutant } & \multirow{2}{*}{$\mathrm{GH}$} & \multirow{2}{*}{$\mathrm{TSH}$} & \multirow{2}{*}{ PRL } & \multicolumn{2}{|c|}{ Fertility } & \multirow{2}{*}{\multicolumn{2}{|c|}{ Reference }} \\
\hline & & & & male & female & & \\
\hline \multicolumn{8}{|l|}{ Mouse } \\
\hline$d w$ & $\downarrow$ & $\downarrow$ & $\downarrow$ & - & - & Snell & (1929) \\
\hline$d f$ & $\downarrow$ & $\downarrow$ & $\downarrow$ & - & - & Schaible \& Gower & $(1961)$ \\
\hline lit & $\downarrow$ & & $\downarrow$ & - & + & Eicher \& Beamer & (1980) \\
\hline$p g$ & (deficiency & of $\mathrm{GH}$ receptor & activity) & va & & King & (1955) \\
\hline \multicolumn{8}{|l|}{ Rat } \\
\hline$d w-1$ & ( & unknown & ) & - & - & Lambert et al. & (1935) \\
\hline$d w-2$ & ( & unknown & ) & - & \pm & Woolley et al. & (1939) \\
\hline$d r$ & $\downarrow$ & $\rightarrow$ & $\rightarrow$ & + & + & Okuma & $(1980)$ \\
\hline$r d w$ & $\downarrow$ & $\downarrow$ & $\downarrow$ & + & - & \multicolumn{2}{|c|}{ present paper } \\
\hline
\end{tabular}

Arrows show histological or endocrinological deficiency, reduction and unchange of GH, TSH and PRL. The $r d w$ rat (present study) is similar to the twe mutant $d w$ and $d f$ mice.

あり,クレチン症とは異なると考えられる。このととは, 実験的な甲状腺摘出時に下垂体に出現してくる甲状腺摘 出細胞 [4] が光顕, 電顕ともに認められないことから明 らかである。

$d r$ ラット [13-15] では, 下垂体 $\mathrm{GH}$ 分泌細胞の完全 な欠損により成長が阻害されていると考えられているが, $r d w$ ラットでは $\mathrm{GH}$ 分泌細胞の減少之甲状腺の発育不 全すなわち T4の産生分泌不全とが相乗的に成長に対し て大きな障害を与えていると考えられる。成長におよぼ す GH, T4 の影響については $d w$ マウスを中心に研究 が進められており，GH あるいは T4 投与の実験で T4 単独投与でも $d w$ マウスはかなりの成長がみられるなど の報告がなされている $[4,19,20]$ 。しかしまだ不明な点 も多く, GH, T4の関連についてはさらに検討を要する と思われる。

卵巣には組織学的な異常を認めなかった。しかし, 交 尾しても妊娠しなかった。乙の雌の不妊は, 血中 PRL 濃度や子宮の状態などについての詳細な検討は行ってい ないため，断定は出来ないが，下垂体前葉 PRL 分泌細 胞の減少に起因する低 PRL 血症による着床, 妊娠維持 機能の不全 [8]によるものと考えられる。一方, 雄は若 齿期の精子形成不全や精細管内腔の拡張などの異常をみ たが，10週齢における精巣重量は正常例と変わらず成熟 後の生殖機能は保たれていた。この機序については不明 である。

脳重量は精巣之同様に正常例のそれに近く, 他の主要 臓器が体重とほぼ一致して正常例のおおよそ40\% 60\% の範囲にあった中で傾向を異にしていた。最近，脳の発
達における $\mathrm{GH} ， \mathrm{~T} 4$ の影響が注目されつつあり [13], 中枢神経発達の分野でも $r d w$ ラットは興味ある材料に なると思われる。

$d w$ や $d f$ マウスでは胸腺退縮や免度不全が認められ ている。しかし, $r d w$ ラットの胸腺重量は正常例の 40 $\%$ 程度であったが，比体重係数は 1.26 であり，組織学 的にあ退縮あるいは発育不全像を認めなかった。今回の 成績からだけでは胸腺免疫系について言及することはで きず今後の検討が待たれる。

交配実験の結果，F 344 系雌亡侏儒症雄の交配による F 1 では発症せず, F 1 同士の交配の F 2 で 23.9\%, F 1 の侏懦症への戻し交配で $52.0 \%$ が発症し, F 1 の F 344 への戻し交配では発症しなかった。この結果は, 劣性単 一遺伝子による遺伝であると仮定したときの理論值に矛 盾しない。また発症に性差がなかったことから，ての侏 儒症は常染色体上の劣性単一遺伝子（遺伝子名：rdw） によると推察された。

過去に報告されているマウス，ラットにおける遺伝性 の侏儒症モデルとの比較を Table 5 に示し, 表中の矢印 で GH, TSH, PRL の形態学的な証明あるいは血中濃 度からの証明による欠損あるいは減少むしくは不変を示 した。表からあ明らかなように, 本報告の $r d w$ ラット は $d w, d f$ の兩マウスに良く似ていると考えられ $[1$, 19], ヒトの下垂体性侏需症や汎下垂体機能低下症のモ デルとして，あるいは内分泌領域の研究材料として有用 性が高いと思われる。 


\section{要 約}

Csk：Wistar-Imamichi 系ラットより見つかった遺 伝性侏儒症 ( $r d w$ 系) ラットについて, 臨木的, 組織学 的, 遺伝学的検討を行った。その結果，乙の侏儒症は常 染色体性劣性単一遺伝子 ( $r d w)$ によって遗伝し, 下垂 体前葉の内分泌細胞とくに GH，PRL，TSH 分泌細胞 の減少および分化不全に起因する下垂体性のものである ことが判明した。総合的に判断すると Snell's dwarf $(d w)$ マウスの病態に類似していると考えられ，内分泌 異常疾患モデルとして有用性が高いと思われる。

\section{文献}

[1] Bartke, A. (1964). Histology of the anterior hypophysis, thyroid and gonads of two types of dwarf mice. Anat. Rec., 149, 225-236.

[2] Christensen, E., and Wilson, D. B. (1981). Fine structure of somatotrophs and mammotrophs in the pituitary pars distaris of the little (lit) mutant mouse. Virchowes Arch. [Cell Pathol], 37, 89-96.

[3] Dingmans, K. P. (1969). On the origin of thyroidectomy cells. J. Ultrastruct. Res., 26, 480-500.

[4] Doherty, P. C., Bartke, A., Dalterio, S., Shuster, L., and Roberson, C. (1980). Effects of growth hormone and thyroxine on pituitary and testicular function in two types of hereditary dwarf mice. J. Exp. Zool., 214, 53-59.

[5] Eicher, E. M., and Beamer, W. G. (1980). New mouse $d w$ allele : genetic location and effects on lifespan and growth hormone levels. J. Hered., 71, 187-190.

[6] Hoeffler, J. P., Boockfor, F. R., and Frawley, L. $\mathrm{S}$. (1985). Ontogeny of prolactin cells in neonatal rats: Initial prolactin secretors also release growth hormone. Endcrinol., 117, 187-195.

[7] Horvath, E., Kovacs, K., Killinger, D. W., Smythe, H. S., Platts, M. E., Weiss, M. S., and Ezrin, C. (1980). Mammosomatotroph cell adenoma of the human pituitary. Proc. Elect. Micro. Soc. Am., 38, 726-727.

[8] Howe, E., Lintern-Moore, S., Moore, G. P. M., and Hawkins, J. (1978). Ovarian development in hypopituitary Snell dwarf mice. The size and composition of the follicle population. Biol. Reprod., 19, 959-964.

[9] King, J. W. B. (1955). Observations on the mutant "pigmy" in the house mouse. J. Genet., 53, 487497.

[10］古藤正男 · 三輪政夫 ·富樫 守 - 辻 紘一郎 - 岡本道生 · 安達二朗(1987). 臸電気インピーダンスによる 4 日性周期
ラットの交配適期判定法，実験動物， 36，201-204.

[11] Lambert, W. V., and Sciuchetti, A. M. (1935). A dwarf mutation in the rat. A mendelian recessive character possibly due to a defect of one of the endocrine glands. J. Hered., 26, 91-94.

[12] Lees, A., Sarlieve, L. L., Neskovic, N. M., Wintzerith, M., and Mandel, P. (1977). Changes in brain components during the development of mice homozygous for the locus "Dwarf" $(d w)$. Neurochem, Res., 2, 11-25.

[13］大熊新一・川島正次 (1980). Spontaneous dwarf rat. (自然発症矮症ラット), 実験動物, 29, 301-304.

[14] 大熊新一 (1982). 遗伝性侏懦症 (ラット) p.92-95, 疾患 モデル動物ハンドブック №.2., 松下 宏, 川俣順一編, 医 歯薬出版, 東京.

[15] 大熊新一 (1984). 自然発症矮症ラットにおける成長ホル モン, 日内分泌会誌, 60, 1005-1014.

[16] Schaible, R., and Gowen, J. W. (1961). A new dwarf mouse. Genet., 46, 896-897.

[17] Snell, G. D. (1929). "Dwarf", a new mendelian recessive charactor of the house mouse. Proc. Natl. Acad. Sci., 15, 733-734.

[18] Sternberger, L. A., Hardy, Jr. P. H., Cuculis, J. J., and Meyer, H. G. (1970). The unlabeled antibody enzyme method of immunohistochemistry. $J$. Histochem. Cytochem., 18, 315-333.

[19] Van Buul-Offers, S. (1983). Hormonal and other inherited growth disturbances in mice with special refernce to the Snell dwarf mouse. Acta Endocrinol., 258, 7-47.

[20] Wallis, M., and Dew, J. A. (1973). The bioassay of growth hormone in Snell's dwarf mice: effects of thyroxine and prolactin on the dose-response curve. J. Endocrinol., 56, 235-243.

[21] Wilson, D. B., and Christensen, E. (1981). Fine structure of somatotrophs and mammotrophs during development of the dwarf ( $d w)$ mutant mouse. $J$. Anat., 133, 407-417.

[22] Woolley, G. W., Roscoe, B., and Cole, L. J. (1939). A new dwarf mutation (dw 2) in Rattus norvegi. cus. Genet., 24, 111.

［23］吉川不二夫 - 石川 博 - 野上春雄 - 白沢信行 - 屋代 隆 (1980). 下垂体前葉細胞の新しい同定 1)Gonadotrophs その 1. 総合臨床, 29, 2051-2053.

［24］吉川不二夫 - 石川 博 - 野上春雄 - 白沢信行 - 屋代 隆 (1980). 下垂体前葉細胞の新しい同定 2)Gonrdotrophs その 2. 総合臨床, 29, 2250-2252.

［25］吉川不二夫・石川 博 - 野上春雄 - 白沢信行 - 屋代 隆 (1980). 下垂体前葉細胞の新しい同定 3) Thyrotrophs. 総合臨床, 29, 2448-2450.

［26］吉川不二夫 - 石川 博 - 野上春雄 - 屋代 隆 - 白沢信行 (1980). 下垂体前葉細胞の新しい同定 4)Corticotrophs. 総合臨床, 29, 2598-2600.

［27］吉川不二夫 - 石川 博 - 野上春雄 - 白沢信行 - 屋代 隆 (1980). 下垂体前葉細胞の新しい同定 5)Prolactin 細胞. 総合臨床. 29, 2823-2825.

［28］吉川不二夫 - 石川 博 - 野上春雄 - 屋代 隆 - 白沢信行 (1980). 下垂体前葉細胞の新しい同定 6)Somatotrophs. 総合臨床, 29, 2989-2991. 